\title{
Interaktywna ekspozycja wartości: światopoglądowe manifestacje polskich intelektualistów w dobie wirtualizacji komunikacji
}

\section{Wstęp}

—unkcji kultury, choćby popularnej, nie można sprowadzić wyłącznie do - rozrywki, tak jak popularność jest nie tylko kapitałem w kategoriach ekonomicznych, ale również kulturowych i politycznych. Choć kultura jest miejscem spotkania różnych wrażliwości, zetknięcia się osób o zupełnie przeciwstawnym światopoglądzie, to jest ona wspólna. Toteż wyjątkową funkcję pełnią twórcy kultury, mający za zadanie kształtowanie tego miejsca, w którym spotkać się mogą wszyscy członkowie wspólnoty. Jednakże współczesna rzeczywistość przejawiająca się $\mathrm{w}$ procesach demokratyzacji wiedzy, mediatyzacji życia publicznego, celebrytyzacji kultury, a przede wszystkim wirtualizacji systemu komunikacji społecznej utrudnia te działania, wprowadzając debatę publiczną $\mathrm{w}$ stan kryzysu, tj. permanentnego konfliktu wartości ${ }^{1}$, komplikującego budowę wspólnego świata.

Powyższe przemiany są wielkim wyzwaniem dla twórców kultury, próbujących zdefiniować na nowo sposoby uczestnictwa w komunikacji masowej, w szukaniu dostępu do swojej publiczności. Ci depozytariusze wartości, których działalność wprost wpisana jest w sferę aksjologii, ciesząc się popularnością, posiadają autorytet $\mathrm{w}$ dziedzinie kultury, ale i potencjał polityczny. Wspiera ich bowiem publiczność, którą ciekawi to, co oni mają do powiedzenia. Współczesność natomiast dostarczyła im narzędzi do kontaktu z tą publicznością, jakiego nigdy

* Dr Tomasz Peciakowski - Instytut Nauk Socjologicznych Katolicki Uniwersytet Lubelski Jana Pawła II, e-mail: tomasz.peciakowski@kul.pl, ORCID: 0000-0003-4031-3346.

${ }^{1}$ D. Tannen, Cywilizacja kłótni. Jak powstrzymać amerykańska wojnę na słowa, Zysk i S-ka, Poznań 2003. 
dotąd twórcy nie mieli. Warto byłoby przyjrzeć się, jak narzędzia te są przez nich wykorzystywane i na ile służą kulturze jako płaszczyźnie komunikowania wartości.

Celem artykułu będzie zatem ustalenie tego, w jaki sposób wartości obecne są w komunikacji wirtualnej polskich zaangażowanych w życie publiczne twórców kultury - jak często i w jaki sposób wykorzystują oni swoje konto na popularnym portalu Facebook nie tylko do promocji swojej twórczości, ale też popularyzowania wartości, które są im bliskie. W artykule jako metodą posłużono się jakościową analizą treści, skupiając się, po pierwsze, na wskazaniu wątków tematycznych obecnych w postach publikowanych przez twórców, po drugie, na wyodrębnieniu tych, które nawiązują do sfery aksjologii, i po trzecie, na analizie dyskursywnej wyodrębnionych materiałów, pozwalającej zgłębić ich treść w kontekście przekazu aksjologicznego. Kluczowe było więc ustalenie, w jaki sposób i poprzez jakiego typu formy twórcy kultury manifestują swoją obecność w sferze aksjologii za pomocą mediów społecznościowych. Gdy zaś o manifeście mowa, artykuł rozpocznie się od wyjaśnienia, dlaczego w tym kontekście rozważań adekwatne jest zaangażowanych twórców kultury określać mianem intelektualistów.

\section{Aksjologiczne podstawy współczesnej komunikacji}

Możliwość komunikowania jest warunkiem tworzenia wspólnoty [komunikować się (communicare) to „czynić wspólnym”. Poprzez wysyłanie i odbieranie komunikatów, tworzenie interakcji, rozwijanie technologii komunikacyjnych, rozszerzanie procesów poznawczych kształtowana jest przestrzeń komunikacyjna (jako dyskurs), w której to grupy społeczne podejmują świadome próby wytworzenia uwspólnionego sensu świata i siebie samych ${ }^{2}$. Podstawową formą tego „uwspólniania” i budowania tożsamości zbiorowej jest zatem komunikowanie interpersonalne, wynika ono z potrzeby utożsamiania się jednostek z różnymi grupami odniesienia - rodziną, rówieśnikami, środowiskiem społecznym (jak sąsiedzi lub znajomi), grupami pracowniczymi, liderami społeczności, liderami opinii etc. - umożliwiającymi codzienną wymianę opinii i informacji oraz współdzielenie wartości. Jednostki jako członkowie społeczności, narodu, obywatele w rolach klientów, petentów, pacjentów, pracowników, pracodawców, uczniów, podatników czy kierowców dzielą się ze sobą prywatnymi doświadczeniami, obserwacjami, deklaracjami co do wyznawanych wartości, które w ten sposób stają się publiczne $e^{3}$. Manifestacja własnych poglądów czy demonstrowanie

2 D. Howarth, Dyskurs, tłum. A. Gąsior-Niemiec, Oficyna Naukowa, Warszawa 2008, s. 14-15.

${ }^{3}$ Zob. J. Habermas, Faktyczność i obowiązywanie. Teoria dyskursu wobec zagadnień prawa i demokratycznego państwa prawa, tłum. A. Romaniuk, R. Marszałek, „Scholar”, Warszawa 2005. 
przywiązania do określonego systemu wartości jest więc kluczowym elementem „uwspólniania”, tj. budowy wspólnoty, oczywiście, gdy dzieje się to w szacunku do innego człowieka.

Tak powstaje wyobrażenie o tym, „kim jesteśmy” - uciera się w dyskursie, $\mathrm{w}$ procesie komunikacji, dzięki integracji wartości kulturowych, tworząc tożsamość zbiorową ${ }^{4}$. Bowiem równolegle do procesów komunikacji odbywają się procesy poznawcze, jednostka zdobywa wiedzę o rzeczywistości, tworzy hierarchię wartości, buduje sobie „obraz świata”: Jednostka „znajduje i stosuje określone słowa i ich sens, te zaś określają w dużej mierze jej dostęp do otaczającego świata, lecz równocześnie objawiają, z jakiego punktu widzenia i w jakim kontekście praktycznym przedmioty były dotychczas dla grupy lub jednostki postrzegalne i ujmowalne"5. Tożsamość zarówno jednostki, jak i zbiorowości jest zatem efektem oddziaływania bardzo wielu czynników, różnorodnych elementów rzeczywistości aktualnej i minionej, a jej przemianom - zwłaszcza na płaszczyźnie zbiorowej - zawsze towarzyszą gorące spory i dyskusje nad kluczowymi wartościami kultury będącymi fundamentem tożsamości. Te są społecznie usankcjonowanymi, typowymi dla danej kultury, uwewnętrznionymi przez ogół członków społeczeństwa drogowskazami ${ }^{6}$. W przestrzeni społecznej muszą więc zostać odpowiednio wyrażone, zrozumiane, przemyślane i przedyskutowane - i dzieje się to w dużej mierze właśnie poprzez dyskurs publiczny.

Jednakże kreowanie i kształtowanie dyskursu publicznego odbywa się za pomocą różnych środków i kanałów komunikowania, dzięki którym wysyłany komunikat staje się publiczny, trafiając do określonej publiczności. Kluczowy staje się więc dostęp do zasobów i narzędzi komunikacyjnych, a nowym źródłem władzy (odznaczającej się m.in. większym wpływem na procesy „uwspólniania") stają się media jako pośrednicy zachodzących interakcji. W tej złożonej przestrzeni komunikacji, w której formowany, uzgadniany, ale i kwestionowany jest ład społeczny, siła przekazu nie jest równa - większe znaczenie mają jednostki o znaczącej pozycji, a także podmioty zbiorowe - organizacje, związki, firmy, media i instytucje publiczne. Ich zasoby i sposoby działania dają większe możliwości, by w tej przestrzeni zaistnieć i wprowadzić swój przekaz. Są głównymi nadawcami komunikatów, ergo to one głównie kształtują ramy dyskursu. Dlatego też jednostki szukając publicznych reprezentacji dla swoich światopoglądów, wyznawanych wartości, ale i interesów, znajdują je nierzadko w mediach masowych, ludziach mediów i liderach opinii, którzy nie tyle zbierają i przekazują informacje, ale często decydują o wyborze i sposobie prezentacji

${ }^{4}$ Zob. L. Dyczewski, D. Wadowski, Wstęp, w: Tożsamość polska w odmiennych kontekstach, red. L. Dyczewski, D. Wadowski, Wydawnictwo KUL, Lublin 2009, s. 5-8.

${ }^{5}$ K. Mannheim, Ideologia i utopia, przeł. P. Miziński, Wydawnictwo Aletheia, Warszawa 2008, s. 33.

${ }^{6}$ L. Dyczewski, Wartości kulturowe ważne dla polskiej tożsamości, w: Tożsamość polska..., s. 152 [149-179]. 
przekazów, kontrolując tym samym obecność tematów, argumentów i aktorów w przestrzeni publicznej ${ }^{7}$.

„Spośród czynników wpływających na kształt tożsamości zbiorowej największą rolę odgrywają elity społeczne, intelektualiści, politycy, duchowni, pisarze, poeci, artyści, autorytety moralne itd. Dziś coraz większą rolę odgrywają różnego rodzaju eksperci, naukowcy, dziennikarze, publicyści, komentatorzy życia publicznego, twórcy kultury popularnej”" . Ten krąg osób „znaczących” dla dyskursu, których określić można jako elity symboliczne, wpływa na zasób publicznie dostępnej wiedzy, kształt i treści dyskursu publicznego, ustala hierarchię spraw ważnych i nieważnych ${ }^{9}$. W ramach tej bardzo zróżnicowanej grupy - z perspektywy aksjologicznej - wyróżnić należy przede wszystkim twórców kultury, tzw. inteligencję twórczą, a więc ludzi, którzy z racji swoich zawodowych powinności mają szczególny dostęp do pewnych osiągnięć uważanych za „wartości kultury”. Ich bowiem działalność wprost wpisana jest w sferę aksjologii, ich autorytet w dziedzinie kultury bazuje na autonomii tworzenia i uniwersalnej płaszczyźnie wartości, charakterystycznej dla świata kultury. Wśród nich szczególną rolę dla dyskursu, publicznego ścierania się wartości i idei pełnią ci twórcy, którzy, mając odwagę cywilną i zdobyty na mocy własnej działalności twórczej autorytet, postanowili zamanifestować swoje przekonania w imię tzw. „wyższej konieczności”.

Mniej więcej od słynnej afery Dreyfusa jest to szeroko opisywane zjawisko $^{10}$ - wystosowywania manifestów, apeli i listów otwartych przez twórców kultury w obronie, ich zdaniem, zagrożonych wartości. Twórcy, wychodząc na scenę publiczną $\mathrm{z}$ autorytetem (wynikającym z popularności i ogólnego uznania), który wywodzi się ze świata kultury, próbują w ten sposób dopominać się o charakterystyczne dla tego świata wartości, łącząc tym samym dwa przeciwstawne sobie światy: kulturę i politykę. Zwykły podpis pod listem staje się tym samym wyrazistym żądaniem politycznym (zmiany dopiero co podjętych działań czy obrania określonego kierunku zmian), traktowany może być jako świadectwo zaangażowania - na bazie bezpośredniej i wspólnej interwencji publicznej twórców w formie listów otwartych czy manifestów. Ich sygnatariuszy można więc definiować jako „twórców kultury, którzy wykraczając poza swoje kompetencje zawodowe, na mocy zdobytego autorytetu angażują się w życie społeczno-polityczne i biorą udział w debacie publicznej, wyrażając poglądy

7 A. Hess, Społeczni uczestnicy medialnego dyskursu politycznego w Polsce. Mediatyzacja i strategie komunikacyjne organizacji pozarządowych, Wydawnictwo Uniwersytetu Jagiellońskiego, Kraków 2013, s. 32-33.

${ }^{8}$ L. Dyczewski, D. Wadowski, Wstęp..., s. 6.

9 Por. Dyskurs elit symbolicznych. Próba diagnozy, red. nauk. M. Czyżewski, K. Franczak, M. Nowicka, J. Stachowiak, Wydawnictwo Akademickie Sedno, Warszawa 2014, s. 7-22.

${ }^{10}$ J. Żarnowski, Intelektualiści, w: Encyklopedia Socjologii, t. 1, red. A. Kojder i in., Oficyna Naukowa, Warszawa 1998, s. 334. 
ideowe bliskie ich wizji świata, wpływając tym samym na swoją publiczność"11, postrzegając ich tym samym jako intelektualistów.

Zaangażowanie twórców kultury w spory ideowe, wspominane powyżej „ścieranie wartości”, jest silnie obecne w polskiej tradycji intelektualnej - chociażby z tego względu, że przez lata kultura polska pełniła także funkcje polityczne, podtrzymując świadomość narodową w czasach zaborów. Rozogniona politycznie II Rzeczpospolita nie dała zbyt wiele przestrzeni twórcom kultury, by mogli skupić się na „sztuce czystej”, bowiem epoka była polityczna ${ }^{12}$. Jako intelektualiści grupa ta zaistniała wyraźniej w polskiej debacie po II wojnie światowej i ich publiczna obecność w sposób nierozerwalny wiąże się z uwikłaniem polskich elit intelektualnych w ówczesny system i socjalistyczną ideologię. Jednak tak rozumiana grupa twórców miała też swój wpływ na transformację systemu w 1989 r., okazała też duże wsparcie dla dokonujących się przemian w latach dziewięćdziesiątych wraz z tworzeniem symbolicznego sukcesu III RP. Intelektualiści jako elita inteligencji pełnili ważną rolę w polskim życiu publicznym i politycznym. Przez znaczną część 30 lat demokratycznej Polski (jeśli nie w całym tym okresie) zajmowali oni uprzywilejowaną pozycję w przestrzeni symbolicznej, mając wpływ na opinię publiczną, tworząc rdzeń i klimat dyskusji o państwie i ważnych dla tej wspólnoty wartościach ${ }^{13}$. Stanowią niejako crème de la crème elit symbolicznych kształtujących polski dyskurs, wpływając znacząco na procesy „ścierania się” wartości. Dlatego też to na tej kategorii społecznej ogniskować się będzie niniejszy artykuł.

\section{Rynek prawdy: wirtualizacja i intelektualiści 2.0}

Współczesna rzeczywistość odbiega jednak zdecydowanie od tej istniejącej 20 czy nawet 30 lat temu - system komunikacji społecznej, politycznej zmienił się w sposób zasadniczy, odmienne stało się też w nim miejsce intelektualistów. Wspomniane przemiany powiązane z powstającym społeczeństwem bez pośredników ${ }^{14}$ przejawiają się chociażby w procesach demokratyzacji wiedzy, m.in. w spadku znaczenia (prestiżu) instytucjonalnych form legitymizacji wiedzy (nowe kryteria legitymizacji ekspertów, deprofesjonalizacja wiedzy

11 T. Peciakowski, Listy nie(pokornych). Intelektualiści w polskim życiu publicznym, TN KUL, Lublin 2019, s. 142.

12 „Jesteśmy dziećmi epoki, epoka jest polityczna. Wszystkie twoje, nasze, wasze dzienne sprawy, nocne sprawy to są sprawy polityczne”. W. Szymborska, Dzieci epoki, w: Ludzie na moście, „Czytelnik”, Warszawa 1986.

13 Zob. T. Peciakowski, Listy nie(pokornych)...

14 W.J. Burszta, Homo Barbarus w świecie algorytmów, „Idea. Studia nad strukturą i rozwojem pojęć filozoficznych" 2016, R. 28, nr 2, s. 9 [5-19]. 
specjalistycznej), co dobrze uwidaczniają media masowe, a zwłaszcza media społeczne. Elity symboliczne coraz silniej rekrutują się z obozu popkultury, a treści o wysokiej jakości intelektualnej rzadziej obecne są w rdzeniu debaty publicznej - na co może wpływać profesjonalizacja akademików i twórców, mediatyzacja życia publicznego lub celebrytyzacja kultury, a najpewniej wszystkie te procesy jednocześnie. Wydaje się natomiast, że niezwykle ważnym elementem (kołem napędowym) wszystkich tego typu przemian jest wirtualizacja systemu komunikacji publicznej, która przeorientowała wektory i zmieniła zasady wytwarzania „uwspólnionego sensu świata”.

Świat wirtualny stał się już właściwie piątym wymiarem rzeczywistości. Komponenty świata realnego przenoszą się do świata wirtualnego, zmieniając dotychczasowe ich funkcjonowanie ${ }^{15}$. Jest to proces, który z powodzeniem wkracza w różnorodne dziedziny życia społecznego, przekształcając praktyki społeczne. Wpływa też coraz wyraźniej na świat wartości. Edukacja aksjologiczna, w tym wychowanie rozumiane jako przyswajanie podstawowych norm i wartości regulujących życie społeczne, dotąd najczęściej odbywała się w rodzinach, szkole, sąsiedzkich grupach rówieśniczych oraz poprzez styczność z wytworami kultury. Obecnie dużą rolę w procesie wychowania odgrywa świat wirtualny, a wpływ treści internetowych na kształtowanie się przekonań i systemów wartości dzieci i młodzieży zdaje się być coraz silniejszy ${ }^{16}$. W zamierzeniach sieć i świat wirtualny miały uczynić system społeczny bardziej otwartym, umożliwić równy dostęp do wiedzy, wytworów kultury, różnorodnych i pluralistycznych informacji, umożliwić różnorodne formy komunikacji, budować otwartą agorę z wieloma opiniami. Jednocześnie jednak niewielu użytkowników sieci wykorzystuje jej aktywizujący potencjał, reprodukując najczęściej konsumpcję medialną właściwą dla mediów masowych (przytoczyć tu można znaną regułę 1\%, mówiącą o tym, że jedynie $1 \%$ internautów produkuje treści, $9 \%$ je edytuje, modyfikuje i rozpowszechnia, a 90\% jedynie przegląda). Powstanie interaktywnych nowych mediów nie wykształciło nowych sposobów odbioru treści - odbiorca głównie jest bierny i kieruje swoją uwagę w stronę dominujących dostawców treści ${ }^{17}$, zmieniła się natomiast forma przekazu oraz rynek dostawców.

Głównym mechanizmem napędzającym życie społeczne w sieci stał się charakteryzowany przed laty przez Zygmunta Baumana mechanizm uwodzenia ${ }^{18}$,

${ }^{15}$ Zob. S. Jaskuła, L. Korporowicz, Kultury narodowe w procesie wirtualizacji, „Politeja” 2014, t. 5, nr 31 (1), s. 7-8.

${ }^{16} \mathrm{~K}$. Ziębakowska-Cecot, Influence of Digital Media on Young Generation's Social and Moral Competences, „Megatrendy a médiä” 2019, nr 6 (1), s. 315-328.

${ }_{17}$ M. Szpunar, Nowe-stare medium. Internet między tworzeniem nowych modeli komunikacyjnych a reprodukowaniem schematów komunikowania masowego, Wydawnictwo IFiS PAN, Warszawa 2012.

${ }_{18}$ Zob. Z. Bauman, Konsumowanie życia, Wydawnictwo Uniwersytetu Jagiellońskiego, Kraków 2009. 
wykorzystywany obecnie nie tylko w reklamie i marketingu czy w polityce i kulturze, ale także w codziennej komunikacji w portalach społecznościowych. Konsekwencją powyższego jest charakterystyczny dla życia publicznego w epoce późnego kapitalizmu - jak pisał Jayson Harsin - rynek prawdy ${ }^{19}$, w którym każdy przekaz dostosowuje się do zasad ekonomii komunikacji. Kultura sporu czy tzw. cywilizacja kłótni ${ }^{20}$ (bazująca na nieustającym komentarzu do rzeczywistości, pobudzaniu dyskusji, medialnych starciach, spekulacjach i kontrowersjach) coraz bardziej wypiera kulturę relacjonowania i informacji (ważniejsze od rozwiniętego i pogłębionego opisu rzeczywistości jest przygotowanie do niego komentarza, najlepiej w kontrze do tzw. „drugiej strony”). Ważniejsze od zdobycia i podania odbiorcom własnych informacji jest skomentowanie informacji cudzych. Proliferację mediów informacyjnych wzmaga nieopanowany przyrost treści internetowych, dających fałszywy pluralizm - to, wracając do J. Harsina, rynek prawdy, produkujący tyle interpretacji rzeczywistości, na ile jest zapotrzebowanie odbiorców. Wzmacnia to chaos i utrudnia zdobycie wiarygodnych informacji o otaczającym nas świecie. Według badań firmy F-secure jedna trzecia polskich internautów o zdefiniowanych poglądach politycznych bardzo często udostępnia niesprawdzone informacje, a poprzez mikrotargeting następuje stopniowa prywatyzacja dyskursu publicznego, znikają pośrednicy weryfikujący odbierane przez użytkowników sieci informacje. Algorytmy dbają o to, by otrzymywać jedynie te treści, które jednostki znają, lubią i cenią, tym samym coraz mniej różnorodnych, wieloźródłowych informacji dociera do użytkowników sieci' ${ }^{21}$.

W tym technologicznym i komunikacyjnym kontekście starają się odnaleźć twórcy kultury, intelektualiści. Internet to eksplozja publikacji internetowych, podcastów, blogów, vlogów, które umożliwiają twórcom kultury wyrażenie swoich pomysłów poza wąskie granice elitarnych stron, niszowych audycji radiowych czy telewizji tematycznych ${ }^{22}$. Może zaobserwować jak to scentralizowany dyskurs o ważności „wiedzy”, „szkolnictwa wyższego”, „kultury wysokiej" ściera się ze zdecentralizowanym dyskursem wychwalającym oprogramowanie open source i nieformalną komunikację w sieci społecznościowej. Joshua Lange twierdzi, że w świetle sokratejskiego modelu dyskursu publicznego, który otwarcie kwestionuje epistemologię konsensusu, sieć może poten-

${ }^{19}$ Czy jak używa to sam J. Harsin w liczbie mnogiej - rynki prawdy (truth markets). J. Harsin, Regimes of Posttruth, Postpolitics, and Attention Economies, „Communication, Culture \& Critique” 2015, t. 8, nr 2, s. 327-333.

20 Tak wybrzmiewa w polskim tłumaczeniu pojęcie, które sformułowała w książce o tym samym tytule Deborah Tannen, w oryginale: „The Argument Culture”. D. Tannen, Cywilizacja kłótni...

21 Zob. Ch. Wylie, Mindf*ck. Cambridge Analytica, czyli jak zepsuć demokrację, tłum. M. Strąkow, Wydawnictwo Insignis, Kraków 2020.

22 D.W. Drezner, Public intellectuals 2.1, „Society” 2009, t. 46, nr 1, s. 49-50. 
cjalnie na nowo zdefiniować rolę twórców, akademików jako przedstawicieli elity intelektualnej w społeczeństwie. Wynikająca z tego równość odtwarza też uniwersytet jako nieograniczoną przestrzeń spotkań dialogu publicznego, a takiego profesora jako zdigitalizowanego intelektualistę publicznego ${ }^{23}$. To samo dotyczy wszystkich twórców kultury, którzy mogą poddać się ogólnym procesom celebrytyzacji i mediatyzacji kultury albo też wykorzystać nowe narzędzia komunikacji wirtualnej do budowania przekazu opartego o wartości. Analiza treści materiałów publikowanych przez twórców kultury poprzez ich konta personalne na Facebooku miała na celu ukazać, w jaki sposób formatują oni swoją komunikację z publicznością w rzeczywistości wirtualnej od strony komunikowanych wartości, jakie są im bliskie.

\section{Analiza treści - zasady i uwarunkowania}

Ze względu na niezwykle trudno uchwytny zbiór zaangażowanych twórców kultury (intelektualistów) zdecydowano się - aby uniknąć zarzutu o zbyt arbitralny dobór treści - na dość mozolną procedurę mającą na celu ustalić zakres zbieranego materiału badawczego. Zdecydowano się główną uwagę skierować na tych twórców, którzy w minionych latach aktywności publicznej dawali już nieraz wyraz swoim poglądom i manifestowali swoje przywiązanie do określonych systemów wartości w charakterystyczny dla intelektualistów sposób - poprzez sygnowanie listów otwartych. Ten sposób przekazywania treści stał się po prostu kolejnym, choć specyficznym, środkiem wyrazu twórców kultury - w formie listu, apelu, protestu, ale przede wszystkim manifestacji ${ }^{24}$ przeciw lub za określonym systemem wartości.

W latach 1989-2014 na łamach „Gazety Wyborczej” i „Rzeczpospolitej” opublikowano w obu gazetach 234 listy otwarte, pod którymi podpisało się w sumie 3184 indywidualnych sygnatariuszy ${ }^{25}$. Gdyby tę bazę danych zredukować do tych twórców kultury, którzy podpisali listy kilkukrotnie (przynajmniej trzy razy), pozostanie 411 osób, które można traktować jako tych najaktywniejszych w zakresie sygnowania listów otwartych. Aby zweryfikować, jak zaangażowani twórcy kultury odnajdują się w obecnej wirtualnej rzeczywistości, próbowano

${ }^{23}$ J. Lange, Rise of the Digitized Public Intellectual: Death of the Professor in the Network Neutral Internet Age, „Interchange” 2015, t. 46, nr 2, s. 95-112.

$24 \mathrm{O}$ „manifestacji pewnej moralności” pisał J. Goćkowski, tłumacząc, że w życiu intelektualnym ludzi nauki (a dotyczy to także ludzi kultury) „(...) nieodzowne są właśnie idee i koncepcje kształtujące zespół poglądów i przekonań dotyczących rzeczywistości tak pojmowanej i tak traktowanej, iż konsekwencją są postawy i postępki, będące manifestacją pewnej moralności”. J. Goćkowski, Autorytety świata uczonych, PIW, Warszawa 1984, s. 242.

25 Lista ukazała się w: T. Peciakowski, Listy nie(pokornych)..., s. 465-476. 
dokonać weryfikacji powyższej listy pod względem obecności sygnatariuszy na najpopularniejszym portalu społecznościowym Facebook (chodziło o konto publiczne prowadzone osobiście przez twórcę). $Z$ analizy odrzucane były konta, które nie zawierały treści i wypowiedzi osobistych, prowadzone były przez asystentów lub profesjonalne agencje, a także te, przy których trudno było ustalić, czy konto faktycznie prowadzone jest osobiście przez danego twórcę. $\mathrm{W}$ ten sposób do analizy wybrano 31 kont twórców kultury ${ }^{26}$, którzy znajdowali się na wspominanej powyżej liście sygnatariuszy wśród pierwszych 150 najaktywniejszych intelektualistów (co oznacza, że w okresie 1989-2014 podpisali list otwarty przynajmniej pięć razy).

Celem badań było ustalenie tego, w jaki sposób wartości obecne są w komunikacji wirtualnej polskich intelektualistów - jak często i w jaki sposób wykorzystują oni swoje konto na popularnym portalu Facebook nie tylko do promocji swojej twórczości, ale też popularyzowania wartości, które są im bliskie. Analiza treści skupiała się zatem, po pierwsze, na wskazaniu wątków tematycznych obecnych w postach publikowanych przez twórców, po drugie, na wyodrębnieniu tych, które nawiązują do sfery aksjologii, i po trzecie, na analizie dyskursywnej wyodrębnionych materiałów, pozwalającej zgłębić ich treść w kontekście przekazu aksjologicznego.

W analizie zebranego materiału - publikowanych przez twórców postów posłużono się metodą jakościowej analizy treści jako tej najbardziej uprawnionej w odniesieniu do sfery komunikacji, treści oraz formy komunikatów tekstowych i wizualnych umieszczonych w określonym kontekście społecznym. Materiał badawczy zbierany był w miesiącach wakacyjnych 2020 r. (lipiec-sierpień), zatem wydarzeniem centralnym niejako szczególnie skłaniającym do manifestacji światopoglądowych były wybory prezydenckie w Polsce, kampania wyborcza, wyniki wyborów i ich konsekwencje. Analiza skupiała się jednak nie na treściach mających charakter typowo agitacyjny i stricte polityczny - najważniejsza była deklaracja aksjologiczna, odwołanie do ważnych idei, innymi słowy: ekspozycja wartości, wystawiona przez twórców kultury na widok ich publiczności.

${ }^{26}$ Ze względu na to, że są to osoby publiczne i ich publiczne aktywności, można je wymienić: Agnieszka Holland, Ireneusz Krzemiński, Olga Tokarczuk, Andrzej Friszke, Jan Pospieszalski, Magdalena Środa, Sławomir Sierakowski, Zbigniew Nosowski, Marcin Król, Andrzej Nowak, Barbara Toruńczyk, Beata Stasińska, Grzegorz Gauden, Jan Widacki, Krystyna Janda, Marcin Wolski, Michał Komar, Janina Jankowska, Krzysztof Czyżewski, Piotr Zaremba, Rafał Ziemkiewicz, Waldemar Kuczyński, Wojciech Maziarski, Dariusz Karłowicz, Magdalena Łazarkiewicz, Ola Hnatiuk, Paweł Milcarek, Andrzej Seweryn, Eugeniusz Smolar, Michał Rusinek, Monika Sznajderman, Ewa Łętowska. 


\section{Społecznościowe manifestacje twórców}

Warto na początku podkreślić, że powyżej opisany dobór materiału powoduje, że uwaga analizy skierowana była na określone pokolenia i specyficzne środowiska twórców: urodzonych w latach pięćdziesiątych i sześćdziesiątych, którzy w III RP wchodzili w dojrzałym wieku, najczęściej ze sporym już dorobkiem i uznaniem, którzy nawykli bardziej do tradycyjnych metod komunikacji, czytania gazet, spotkań autorskich, dyskusji publicznych, a w szczególnych sytuacjach, do podpisywania listów otwartych ${ }^{27}$. To grono twórców będące wciąż na marginesie świata celebrytów, przyzwyczajone raczej do nomenklatury i etykiety inteligenckiej. Stanowią oni reprezentację pokolenia twórców pełniących obecnie (na przełomie drugiej i trzeciej dekady XXI wieku) w kulturze polskiej rolę centralną - jako osoby o ugruntowanej już pozycji i zbudowanym autorytecie. Spośród podanych osób w tej próbie $42 \%$ stanowią dziennikarze i publicyści, 39\% akademicy, 23\% pisarze, krytycy literaccy i wydawcy, a 13\% artyści - filmowcy (możliwość współwystępowania kategorii przy jednej osobie). Największą popularnością na Facebooku cieszą się profile Krystyny Jandy (389 tys. fanów), Olgi Tokarczuk (172 tys.) i Rafała Ziemkiewicza (106 tys.), liczba fanów dla pozostałych waha się między kilkadziesiąt a kilkanaście tysięcy przy średnich dla branż (wg liczby fanów): 347 tys. - muzycy i zespoły; 291 tys. - telewizja; 260 tys. - osoby; 204 tys. - rozrywka ${ }^{28}$. Z wyjątkiem być może ww. aktorki nie są to więc liderzy popularności w mediach społecznościowych, u tych bowiem liczba obserwujących w polskich warunkach sięga 1-2 mln użytkowników.

W analizowanym okresie na 31 profilach opublikowano w sumie 1152 posty: $39 \% \mathrm{z}$ nich stanowiły materiały autopromocyjne, informujące o wydarzeniach, w których twórca bierze udział, przedstawiające wytwory, których jest autorem, omawiające zdarzenia minione, tj. premiery, spotkania, rozdania nagród itp.; 26\% postów to komentarze bieżące (polityczne, sportowe, muzyczne etc.), często odsyłające do artykułu na innym portalu, w tej kategorii zgrupowano posty bez wyraźnego odniesienia do wartości; w końcu $23 \%$ - posty odwołujące się do sfery aksjologii, popularyzujące określone postawy, namawiające do sprzeciwu, uwypuklające konkretne wartości; 7\% - żarty, memy, zabawne materiały wizualne i audiowizualne; $4 \%$ - myśli, aforyzmy, cytaty; $1 \%$ - inne. Wśród postów odwołujących się do sfery aksjologii wyróżniono te, które odwoływały się wprost do takich wartości jak wolność (73 razy), prawa człowieka

${ }^{27}$ W Polsce tradycja pisania listów otwartych rozpoczęła się przede wszystkim od Listu 34 z 1964 r., późniejsze tego typu inicjatywy, zwłaszcza z lat siedemdziesiątych (np. List 59, List 101), rozpowszechniły taką formę komunikacji i protestu wśród twórców, budując jej symboliczną wymowę i nadając jej odpowiedniego prestiżu (wąski krąg sygnatariuszy).

28 Por. Raport: Facebook Trends Polska Sierpień 2020, Sotrender, 2020. 
(33 razy), miłość (26 razy), demokracja (53 razy), Polska (12 razy), państwo prawa (14 razy), szacunek (3 razy), prawda (8 razy), równość (9 razy). Oczywiście, w grupie twórców, których posty poddano niniejszej analizie, znajdują się osoby o różnych, często przeciwstawnych poglądach. Należy pamiętać, że grupa ta nie jest reprezentatywna dla środowiska twórców, ale stanowi ciekawy zbiór osobistości - celem analizy nie było jednak zarysowanie politycznych czy ideologicznych różnic między twórcami, a raczej zwrócenie uwagi na pewne podobieństwa: to, w jaki sposób i poprzez jakiego typu formy współcześni intelektualiści manifestują swoją obecność w sferze aksjologii za pomocą mediów społecznościowych.

Przekaz aksjologiczny uwidaczniał się w postach twórców na Facebooku na różne sposoby, które ująć można w czterech formach, stanowiących jednocześnie stopniowalną typologię komunikacji zaangażowanej: rekomendacja, lokowanie idei, eksternalizacja oraz protest. Najłagodniejszą formą perswazyjną stanowi rekomendacja - chodzi o polecenie, zwrócenie uwagi odbiorcom, że coś jest ciekawe i warte zainteresowania. Najczęściej za pomocą podlinkowanego materiału (artykułu, raportu, video, udostępnianego posta innej osoby) twórcy zwracali uwagę na ważne dla nich sprawy - ocieplenie klimatu, smog, zmiany w bioróżnorodności gleby, wycinka drzew, nierówności ekonomiczne, argumenty za lub przeciw aborcji, relacja państwo-Kościół, prawa mniejszości seksualnych, poprawność polityczna - jednak bez zajmowania wyraźnego stanowiska, bowiem sam udostępniany materiał zawierał już określony stosunek do rzeczywistości. Nie rzadko twórca polecał swój własny artykuł lub materiał o nim, gdzie wykładał swoje stanowisko na dany temat - na portalu społecznościowym polecał go jednak w sposób stonowany, za pomocą cytatu lub wyrażenia typu „Polecam uwadze”.

Inną formą promocji wartości obecnej w analizowanych postach było tzw. lokowanie idei (idea placement), „młodszy brat” mechanizmu znanego z reklamy jako lokowanie produktu (czyli odpłatne umieszczanie marki w tle przekazu medialnego/kulturowego), używanego także często w mediach społecznościowych. Lokowanie idei - czyli promocja określonych postaw, wartości i zachowań - znane i wykorzystywane jest w polskim systemie medialnym ${ }^{29}$. Użycie tego pojęcia w przypadku komunikacji twórców na Facebooku nie ma na celu sugerowania, że idea placement w ich wykonaniu ma charakter odpłatny, ale że twórcy poprzez swój kanał komunikacji z fanami intencjonalnie włączają przekaz ideowy i aksjologiczny w publikowane posty, zdjęcia, materiały wideo, pośród treści dotyczących codziennego życia - jak zdjęcie ze spaceru po

${ }^{29}$ M. Hoły-Łuczaj, K. Łuczaj, Lokowanie idei w przekazie medialnym jako zaangażowanie w warunkach wspólnego kapitalizmu, „Zeszyty Naukowe Towarzystwa Doktorantów UJ. Nauki Społeczne” 2013, nr 7 (2), s. $28-31$. 
mieście z wyeksponowaną tęczową torbą i podpisem „\#loveislove”, wspólnego rysowania z dziećmi kredkami tęczowej flagi, joggingu w czapce ze znaczkiem „Polski Walczącej”. Na swój sposób jako lokowanie idei można odebrać wpis Olgi Tokarczuk z 10 lipca 2020 r.: „mądra, normalna rozmowa” (podpis pod trzema pogodnymi, pełnymi serdeczności zdjęciami z jednym $\mathrm{z}$ kandydatów na prezydenta, wraz z kampanijnym tagiem kandydata).

Eksternalizacja jako kolejny typ komunikacji zaangażowanej używanej przez twórców w mediach społecznościowych to uzewnętrznienie własnych emocji, poglądów, wiąże się z wyrażeniem wprost własnego zdania, przyznania się do określonego światopoglądu, wskazania bliskich wartości. W analizowanym czasie twórcy często sięgali po tę formę w trakcie kampanii prezydenckiej, zapowiadając swoją decyzję wyborczą, nie rzadko za pomocą argumentów odwołujących się do wartości, jak np. Andrzej Friszke, 5 lipca 2020 roku: „(..) niszczy ten system, przywraca dyktaturę jednej partii i jednej prawdy, i wyprowadza nas z Europy, ku... No właśnie, jaka jest alternatywa dla demokracji liberalnej i Unii Europejskiej? To są nadrzędne przyczyny, dla których oddam głos na (...)”. W ten i podobny sposób twórcy komunikowali też swój pogląd dotyczący aborcji, płci kulturowej, praw osób LGBT, pedofilii w Kościele i poprawności politycznej.

Protest $\mathrm{w}$ analizowanym okresie występował przede wszystkim jako forma utożsamiania się z uczestnikami ówczesnych wydarzeń ulicznych w Polsce charakteryzował się wyraźnym sprzeciwem wobec postępowania władz państwowych, wysoką emocjonalnością przekazu, dużym zaangażowaniem i poparciem dla haseł postulowanych przez „stronę uliczną", często wspartym „podawanymi dalej" relacjami z ulicy. W okresie, którego dotyczyła analiza, zdecydowanie najczęstszym motywem protestu obecnym na profilach twórców przeciwnych rządowi były prawa osób mniejszości seksualnych (LGBT+), pochody i zamieszki z tym związane, które odbywały się w czasie wakacyjnym w stolicy kraju. Wydarzenia te doczekały się także listu otwartego intelektualistów do Przewodniczącej Komisji Europejskiej, inspirowanego przez Agnieszkę Holland, pod którym podpis złożyło 76 uznanych twórców kultury (pisarze, akademicy, twórcy filmowi) z różnych państw świata, w tym z Polski. Poza reżyserką list podpisali także inni polscy twórcy, m.in.: Olga Tokarczuk, Agnieszka Graff, Jan Komasa, Andrzej Leder, Paweł Pawlikowski, Dorota Masłowska, Adam Zagajewski. List „(...) w obronie podstawowych europejskich wartości - równości, niedyskryminacji, szacunku dla mniejszości (...)"30 został zamieszczony także na profilach na Facebooku przez A. Holland i O. Tokarczuk, podany dalej m.in. przez K. Jandę. W analizowanym okresie pojawił się też inny list otwarty, który

${ }^{30}$ List solidarności i protestu do Ursuli von der Leyen, przewodniczacej Komisji Europejskiej, cyt. za: P. Pacewicz, Almodovar, Atwood, Ash, Auster, Coetzee, Tokarczuk wzywaja KE do potępienia homofobii w Polsce, www.oko.press z 17.08.2020 r. (stan na dzień 10.10.2020). 
5 sierpnia 2020 roku pojawił się np. na profilu R. Ziemkiewicza - List pisarzy w obronie wolności słowa, jako protest przeciwko cenzurze i poprawności politycznej (podpisany m.in. przez Jacka Dukaja czy Jacka Piekarę).

Ekspozycje wartości na analizowanych facebookowych profilach polskich twórców kultury w okresie wakacyjnym w 2020 r. charakteryzował wysoki stopień polityczności, wpisywania ważnych deklaracji o charakterze aksjologicznym w bieżące spory ideowe, z wyraźną wymową pro-, a głównie antyrządową, albo $\mathrm{z}$ wyrażonym wprost poparciem dla określonego kandydata w wyborach. Rzadziej profile te były miejscem pogłębionej refleksji, zwrócenia uwagi na bardziej skomplikowane zjawiska, dobrze opracowane diagnozy, szerokie debaty. Bardzo często objawiała się w nich supozycja „my-oni”, przy czym „onych” nie zawsze odgrywał rząd, często inni obywatele, osoby o innych poglądach. Rzadko można było odnaleźć wypowiedzi, takie jak ta Andrzeja Nowaka z 21 lipca 2020 r., polecającego materiał wideo ze swoim udziałem: „Namawiałem i namawiam do tego, by próbować wychodzić ze swoich kokonów, a kiedy jest okazja - nawiązywać rozmowę z (zadowolonymi/ sfrustrowanymi/przestraszonymi) mieszkańcami drugiego kokonu. (...) Nie bójmy się rozmawiać!”.

\section{Zakończenie}

Dominująca rola myślenia ekonomicznego w polu produkcji kultury poddaje jego wytwory ciągłemu plebiscytowi, co zmienia hierarchizacje i kształtuje autorytet kultury w oparciu o wyniki finansowe, a nie symboliczne konstatacje. Mediatyzacja kultury, polityki i życia publicznego ciągle powoduje, że to medialni giganci kreują debatę, tworzą narrację i ustalają zakres przekazu, decydując ponadto o jego formie. Twórcy kultury, jeśli chcą kierować się do dużej publiczności, muszą akceptować te narzucone przez media reguły - logikę komercji i presji czasu, a im mniejszy kulturowy kapitał i uznanie, jakim cieszy się twórca, tym większa podatność na mediatyzację przekazu i zaakceptowanie formuły celebrytyzmu. Media społecznościowe dają twórcy możliwość tworzenia reguł własnej komunikacji, choć każdy sukces ma swoją cenę.

Media społecznościowe znoszą częściowo barierę między życiem prywatnym a publicznym - twórcy kultury we własnych rękach posiadają narzędzie, które o wiele częściej niż było to w „epoce gazet” czy „epoce telewizji” stwarza możliwość wyrażenia poglądów, podzielenia się własną opinią, ukazania skrawka swojego życia „zanurzonego w wartościach”31. Trudniej wówczas tworzyć

31 „Żyjemy zanurzeni w wartościach. Ale wartości te mogą pozostać dla nas abstrakcjami; wtedy ich życiodajna siła jest jakby zamrożona. Wartości muszą się urzeczywistniać w naszej codzienności. 
w „wieży z kości słoniowej”, zwłaszcza że nie tego oczekują fani, żwawiej reagując na każdą kontrowersję. Twórcy kultury, także ci o uznanej pozycji społecznej, w mediach społecznościowych sięgają po narzędzia komunikacji zaangażowanej, a także angażującej - największą reakcję fanów budzą posty silnie emocjonalne, wyraźnie nacechowane aksjologicznie, ukazujące wyraźne stanowisko twórcy w danej kwestii - wówczas mogą liczyć na reakcję zarówno zwolenników, jak przeciwników sprawy.

Dla internetowych zasięgów i algorytmów kluczowe jest właśnie zaangażowanie obserwujących, ich aktywność, mniej istotne jest to, czy jest ono wyrazem poparcia czy sprzeciwu. Mechanizmy tworzące media społecznościowe sprzyjają więc polaryzacji. Tyle że wartości ciągle występujące w kontekście świata biegunowego - „za” i „przeciw”, „dobre” i „złe”, „białe” i „czarne” - coraz bardziej tworzą opisywaną wcześniej „cywilizację kłótni”, zaczynają bardziej dzielić niż łączyć, uniwersalność i integracyjny charakter kultury schodzi na plan dalszy.

Intelektualiści zawsze toczyli spory, twórcy kultury byli mniej lub bardziej zaangażowani ideowo, co nie musiało oznaczać od razu zaangażowania w politykę tej czy innej partii, w zamierzeniu jednak dotyczyło bitew o ludzkie serca i umysły ${ }^{32}$. Zainspirowany myślą marksistowską Raymond Williams pisał, że sztuka, podobnie jak inne rodzaje ludzkiej działalności, jest zawsze zaangażowana, przedstawia bowiem wyselekcjonowane wydarzenia $\mathrm{z}$ określonej perspektywy, a samo zaangażowanie to tyle, co „wybór stanowiska aksjologicznego" ${ }^{33}$. Nawet jeśli tak jest, to dzięki temu, że kultura to komunikowanie wartości. „Za pomocą kultury człowiek porusza się w przestrzeni wielkiej ludzkiej wspólnoty, a przez swoją aktywność pragnie skomunikować się tak z drugim człowiekiem, jak i z samym sobą"34.

Konflikt i spór są cenne, jeśli tworzą kontekst dla rozważań nad istotą bycia człowiekiem, obywatelem, jeśli kształtują środowisko dla rozkwitu debaty publicznej i rozmowy, ubogacając tym samym odbiór wytworów kultury. Tego typu ścieranie się wartości tworzy wspólnotę i tożsamość zbiorową. Media społecznościowe na swój sposób żywiące się konfliktem mogą tego typu ścieranie się utrudniać, zamykając adwersarzy w swoich własnych środowiskach. Intelektualiści stoją zatem przed pokusą, mogąc wykorzystywać wirtualne narzędzie do nakręcania popularności poprzez eksponowanie kontrowersji, podziałów i konfliktów. Z jednej strony zaangażowany twórca kultury jawi się jako intelektualny partyzant, uderzający w powielane utarte komunały i utrwa-

Wówczas codzienność ożyje i odnajdziemy w niej wartość życia”. M. Heller, Wszechświat jest tylko droga. Kosmiczne rekolekcje, Wydawnictwo Znak, Kraków 2012, s. 22.

${ }_{32}$ Zob. F. Furedi, Gdzie się podziali wszyscy intelektualiści?, PIW, Warszawa 2004, s. 41.

${ }^{33}$ R. Williams, Marksizm i literatura, tłum. A. Chojnacki i E. Kasperski, PWN, Warszawa 1989, s. 331 .

${ }^{34}$ G. Żuk, Edukacja aksjologiczna. Zarys problematyki, Wydawnictwo UMCS, Lublin 2016, s. 91. 
lone kanały komunikacji, ale $\mathrm{z}$ drugiej staje się mimowolnym przewodnikiem racjonalizującym zbiorowe dążenia i emocje, dodając im w dyskursie publicznym większej siły przebicia. Taka rola w technologicznym świecie Web 2.0 ma wszelkie podstawy do rozwoju, pytanie tylko, czy intelektualna kontestacja nie przerodzi się w rodzaj kulturowej celebracji na opak - celebrytyzacji monetyzującej kłótnie.

\section{Bibliografia}

Bauman Z., Konsumowanie życia, Wydawnictwo Uniwersytetu Jagiellońskiego, Kraków 2009.

Burszta W.J., Homo Barbarus w świecie algorytmów, „Idea. Studia nad strukturą i rozwojem pojęć filozoficznych" 2016, R. 28, nr 2, s. 5-19.

Drezner D.W., Public intellectuals 2.1 ,,Society"2009, t. 46, nr 1, s. 49-54, DOI: 10.1007/s12115-008-9158-5.

Dyczewski L., Wadowski D., Wstęp, w: Tożsamość polska w odmiennych kontekstach, red. L. Dyczewski, D. Wadowski, Wydawnictwo KUL, Lublin 2009, s. 5-8.

Dyczewski L., Wartości kulturowe ważne dla polskiej tożsamości, w: Tożsamość polska w odmiennych kontekstach, red. L. Dyczewski, D. Wadowski, Wydawnictwo KUL, Lublin 2009, s. 149-179.

Dyskurs elit symbolicznych. Próba diagnozy, red. nauk. M. Czyżewski, K. Franczak, M. Nowicka, J. Stachowiak, Wydawnictwo Akademickie Sedno, Warszawa 2014.

Furedi F., Gdzie się podziali wszyscy intelektualiści?, PIW, Warszawa 2004.

Goćkowski J., Autorytety świata uczonych, PIW, Warszawa 1984.

Habermas J., Faktyczność i obowiązywanie. Teoria dyskursu wobec zagadnień prawa i demokratycznego państwa prawa, tłum. A. Romaniuk, R. Marszałek, „Scholar”, Warszawa 2005.

Harsin J., Regimes of Posttruth, Postpolitics, and Attention Economies, "Communication, Culture \& Critique" 2015, t. 8, nr 2, s. 327-333, DOI: 10.1111/cccr.12097.

Heller M., Wszechświat jest tylko drogą, kosmiczne rekolekcje, Wydawnictwo Znak, Kraków 2012.

Hess A., Społeczni uczestnicy medialnego dyskursu politycznego w Polsce. Mediatyzacja i strategie komunikacyjne organizacji pozarządowych, Wydawnictwo Uniwersytetu Jagiellońskiego Kraków 2013.

Hoły-Łuczaj M., Łuczaj K., Lokowanie idei w przekazie medialnym jako zaangażowanie w warunkach wspólnego kapitalizmu, "Zeszyty Naukowe Towarzystwa Doktorantów UJ. Nauki Społeczne” 2013, nr 7(2), s. 23-40.

Howarth D., Dyskurs, tłum. A. Gąsior-Niemiec, Oficyna Naukowa, Warszawa 2008, s. 14-15.

Jaskuła S., Korporowicz L., Kultury narodowe w procesie wirtualizacji, „Politeja” 2014, t. 5, nr 31 (1), 2014, s. 7-30.

Lange J., Rise of the Digitized Public Intellectual: Death of the Professor in the Network Neutral Internet Age , „Interchange” 2015, t. 46, nr 2, s. 95-112.

Mannheim K., Ideologia i utopia, tłum. P. Miziński, Wydawnictwo Aletheia, Warszawa 2008.

Pacewicz P., Almodovar, Atwood, Ash, Auster, Coetzee, Tokarczuk wzywają KE do potępienia homofobii w Polsce, www.oko.press z 17.08.2020 r. (stan na dzień 10.10.2020).

Peciakowski T., Listy nie(pokornych). Intelektualiści w polskim życiu publicznym, TN KUL, Lublin 2019.

Raport: Facebook Trends Polska Sierpień 2020, Sotrender, 2020.

Szpunar M., Nowe-stare medium. Internet między tworzeniem nowych modeli komunikacyjnych a reprodukowaniem schematów komunikowania masowego, Wydawnictwo IFiS PAN, Warszawa 2012.

Szymborska W., Ludzie na moście, „Czytelnik”, Warszawa 1986.

Tannen D., Cywilizacja kłótni. Jak powstrzymać amerykańskq wojnę na słowa, Zysk i S-ka, Poznań 2003. 
Wylie Ch., Mindf*ck. Cambridge Analytica, czyli jak zepsuć demokrację, tłum. M. Strąkow, Wydawnictwo Insignis, Kraków 2020.

Ziębakowska-Cecot K., Influence of Digital Media on Young Generation's Social and Moral Competences, "Megatrendy a médiá" 2019, nr 6 (1), s. 315-328.

Żarnowski J., Intelektualiści, w: Encyklopedia socjologii, t. 1, red. A. Kojder i in., Oficyna Naukowa, Warszawa 1998, s. 334-337.

Żuk G., Edukacja aksjologiczna. Zarys problematyki, Wydawnictwo UMCS, Lublin 2016.

\section{Streszczenie}

W artykule podjęto próbę ustalenia tego, w jaki sposób wartości obecne są w komunikacji wirtualnej polskich intelektualistów zaangażowanych w życie publiczne twórców kultury. W publikacji zastosowano jakościową analizę treści, skupiając się - po pierwsze - na wskazaniu wątków tematycznych obecnych w postach publikowanych przez twórców, po drugie, na wyodrębnieniu tych, które nawiązują do sfery aksjologii, i po trzecie, na analizie dyskursywnej wyodrębnionych materiałów, pozwalającej zgłębić ich treść w kontekście przekazu aksjologicznego.

Intelektualiści w mediach społecznościowych sięgają po narzędzia komunikacji zaangażowanej, a także angażującej - emocjonalnej, nacechowanej aksjologicznie, nie rzadko budzącej kontrowersje. $\mathrm{W}$ artykule omówiono cztery formy budowanej w ten sposób komunikacji: rekomendację, lokowanie idei, eksternalizację oraz protest.

Słowa kluczowe: wartości, dyskurs publiczny, intelektualiści, wirtualizacja, Facebook

\section{Interactive exposition of values: Polish intellectuals' worldview manifestations in the era of virtualized communication}

\section{Summary}

The article attempts to establish in what way values manifest themselves in the virtual communication undertaken by Polish intellectuals - creators of culture involved in public life. The article uses qualitative content analysis as its research method. The analysis focuses, firstly, on identifying thematic threads present in posts published by the researched authors; secondly, on distinguishing those threads that relate to axiology; and thirdly, on the discursive analysis of the selected material, in order to explore deeply their content for its axiological message.

When on social media, intellectuals use tools of engaged and engaging communication - emotional, axiologically marked, often controversial. The article discusses four forms of communication built this way: recommendation, idea placement, externalization and protest.

Key words: values, public discourse, intellectuals, virtualization, Facebook 